\title{
Rapid and Simultaneous Determination of Feed Nutritive Values by Means of Near Infrared Spectroscopy
}

\author{
Samadii, $^{\mathrm{a},}$, S. Wajizah ${ }^{\mathrm{a}}$, \& A. A. Munawar ${ }^{\mathrm{b}, *}$ \\ aDepartment of Animal Science, Faculty of Agriculture, Syiah Kuala University \\ bDepartment of Agricultural Engineering, Faculty of Agriculture, Syiah Kuala University \\ Jalan Tgk. Hasan Krueng Kalee No.3, Kopelma Darussalam, Syiah Kuala, Banda Aceh 23111, Indonesia \\ *Email of corresponding author: aamunawar@unsyiah.ac.id or samadi177@unsyiah.ac.id \\ (Received 07-01-2018; Reviewed 01-03-2018; Accepted 11-04-2018)
}

\begin{abstract}
Feed plays a significant role in livestock production worldwide. Digestibility of feed such as in vitro dry matter digestibility (IVDMD) and in vitro organic matter digestibility (IVOMD) as well as the fractions of crude fiber such as neutral detergent fiber (NDF) and acid detergent fiber (ADF) can be used as indicators of feed quality. To determine these nutritive parameters, several methods based on solvent extraction and other laboratory analyses are widely employed which are normally time consuming and may cause pollution since this analysis involves chemical materials. Near infrared spectroscopy (NIRS) is one of rapid alternative methods that can be considered to be applied due to its advantages. Therefore, the main objective of this present study is to apply NIRS in determining IVDMD, IVOMD, NDF, and ADF of animal feed samples simultaneously. Reflectance spectra were acquired for animal feed samples in wavelength range from 1000 to $2500 \mathrm{~nm}$. Actual quality and nutritive values were measured by standard laboratory method. Spectra data were corrected by baseline shift correction (BSC), standard normal variate (SNV), and de-trending (DT). Prediction models were developed using principal component regression. Superior results for IVDMD, IVOMD, and NDF predictions were achieved using SNV with correlation coefficient $(r)$ and RPD index of 0.93 and 2.78 for IVDMD, 0.90 and 2.35 for IVOMD, and 0.89 and 2.31 for NDF, respectively. ADF nutritive value was predicted accurately using DT spectrum with $r$ and RPD index of 0.94 and 3.00, respectively. It may be concluded that NIRS can be used and applied as a rapid and simultaneous method in determining nutritive values of feed samples.
\end{abstract}

Keywords: NIRS, feed, nutritive value, infrared spectroscopy

\section{INTRODUCTION}

Feeding is one of the most important factors influencing the success of animal productions and this component spends about $70 \%$ of production cost in livestock industries. Utilization of crop residues from agro-industry byproducts as animal feed is one of the solutions to reduce feed cost. However, nutritive values and digestibility of feed using agro-industry byproducts were low and need several methods to be applied for improving the quality and digestibility of feed (Wanapat et al., 2009; Santoso et al., 2014; Wajizah et al., 2015; Samadi et al., 2015; Samadi et al., 2016; Wiryawan et al., 2017). Feed fermentation technology by microbial administration seems to be a practical and promising alternative to increase nutritional values of agro-industry residues and produce improved value-added products. Study conducted by Samadi et al. (2016) concluded that fermentation of complete feed based on sago residues significantly influenced the values of $\mathrm{NH}_{3}, \mathrm{VFA}$, IVOMD, and IVDMD.
Feed evaluation plays a very important point in animal enterprise by formulation of animal feed to obtain high production of animals. Several methods are widely employed to analyze animal feed. However, most of them are based on wet chemical analysis which are destructive in nature, involve chemical materials, complicated sample preparations, time consuming, and may cause pollutions. Thus, an alternative fast, robust, and effective method is required to analyze feed quality parameters (Samadi \& Yu, 2011, Samadi et al., 2013; Munawar et al., 2016; Samadi et al., 2018).

In last few decades, near infrared reflectance spectroscopy (NIRS) becomes one of the most promising and suitable alternative methods that can be used in many areas, including in agriculture and livestock production sectors. This method can analyze chemical or quality properties without any specific sample preparation, environmental friendly since no chemical materials are used, as well as fast and non-destructive (Munawar et al., 2013., Porep et al., 2015). In addition, NIRS also has the ability to predict and determine desired quality or 
nutritive parameters simultaneously using the same spectral data (Nicolai et al., 2007, Tsenkova et al., 2011).

The key element for an efficient NIRS analysis is the development and construction of a good prediction model to extract all the existed information and sometime hidden in the spectrum which are related to the studied and desired quality attributes of biological objects. In addition, to obtain accurate and robust prediction model, it is possible to process the NIR spectral data with mathematical transformations of the spectrum using various types of pretreatments reducing and eliminating the effects unrelated to the property of interest (Huang et al., 2008; Porep et al., 2015).

Several spectra pre-processing methods have been widely tested and employed to enhance the accuracy and robustness of prediction in NIRS model. These methods such as standard normal variate (SNV), baseline shift correction (BSC), spectra smoothing, orthogonal signal correction (OSC), spectra derivatives, and de-trending (DT) are common spectra pre-processing that are applied prior to prediction modelling (Nicolai et al., 2007; Cozzolino et al., 2011). Furthermore, NIRS prediction models can be constructed using several regression approaches like multiple linear regression (MLR), stepwise regression (SR), principal component regression (PCR), and partial least square regression (PLSR). Recently, non-linear regression approaches such as support vector regression (SVR) and artificial neural networks (ANN) are also applied to the data of spectroscopic model (Munawar et al., 2016; Nawi et al., 2013; Balabin \& Lomakina, 2011; Balabin \& Smirnov, 2011). Therefore, the main objective of this present study is to investigate the feasibility of NIRS as an alternative method in determining animal feed quality parameters (IVDMD, IVOMD, NDF, and ADF). Different spectra pre-processing (BSC, SNV, and DT) methods and the analyses of the accuracy and robustness of the prediction were employed in this study. Prediction models were constructed using principal component regression (PCR) method.

\section{MATERIALS AND METHODS}

\section{Feed Samples}

In this study, feed samples (sago residues) were fermented in the period of $0,7,14,21$, and 28 days by using commercial fermentation product (SBP-Saus Burger Pakan $\left.{ }^{\circledR}\right)$ with five replications for each treatment. Therefore, there were 25 samples for further chemical analysis. Fermented samples were analyzed for NDF (AOAC, 2012: method 2002.04) and ADF (AOAC, 2012: method 973.18) at the Laboratory Test and Feed Certification, Bekasi, West Java. IVDMD and IVOMD were performed at the Laboratory of Nutrition and Dairy Science, Nutrition and Feed Technology Department, IPB, Bogor. Tilley \& Terry (1963) methods were applied to analyze IVDMD and IVOMD known as a two-stage technique for in vitro digestion in which in the first step samples were fermented for $48 \mathrm{~h}$ in a buffer solution containing rumen fluid followed by a digestion with pepsin in an acid solution for $48 \mathrm{~h}$.

\section{NIR Feed Spectrum}

Near Infrared spectra data for feed samples were taken by irradiation of halogen lamp onto a $30 \mathrm{~g}$ of bulk, homogenized feed samples. Spectra data were acquired and recorded in the form of diffuse reflectance spectra data in wave length range of 1000-2500 nm or in wave numbers of $4000-10000 \mathrm{~cm}^{-1}$. Diffuse reflectance spectra data were saved in two different file formats ( ${ }^{*}$.SPA and *.CSV) that were used for further data analysis.

\section{Outlier Removal}

Spectra data were firstly projected onto principal component analysis (PCA) followed by Hotelling $\mathrm{T}^{2}$ ellipse for outlier detection. If there were any data outside the ellipse, then these spectra data were noted as outlier and removed prior to further analysis (Munawar et al., 2016).

\section{Spectra Correction}

Spectra correction was performed after outlier removal. It compensates and eliminates scatter effects that may influence the model prediction performance. Spectra correction was applied using baseline shift correction (BSC), standard normal variate (SNV), and de-trending (DT) correction methods. Spectra correction tends to remove spectral noises due to light scattering, sensor curvature, over-heated effects, and multiplicative effects.

\section{Prediction Models}

Once spectra corrections were completed, the prediction models were constructed using all spectrum (raw, BSC, SNV, and DT) to predict quality and nutritive parameters of feed samples. The models were developed using principal component regression (PCR) and validated using full leave one out cross validation.

Model performances, accuracy, and robustness were quantified using several statistical parameters such as: coefficient of determination $\left(\mathrm{R}^{2}\right)$, correlation coefficient (r), root mean square error (RMSE), residual predictive deviation (RPD), and the number of latent variable (LV). It is obvious that good model should have high $\mathrm{R}^{2}, \mathrm{r}$, and RPD with lower number of LV and RMSE (Nicolai et al., 2007).

\section{RESULTS}

\section{Effect of Fermentation Time on IVDMD, IVOMD, NDF and ADF Contents}

Table 1 indicated that fermentation time increased significantly $(\mathrm{P}<0.05)$ IVDMD, IVOMD and reduced the content of NDF and ADF of sago residues. Fermentation of sago residues up to a-21 d improved IVDMD, IVOMD to $19.34 \%$ and $22.19 \%$, respectively, compared to control. However, after a-21 d fermentation, the percentage of IVDMD, IVOMD tended to decrease, but it was still higher compared to control. NDF content 
decreased about $55.07 \%$ at 21 -d fermentation compered to control. The percentage of ADF in sago residues reduced about $16.41 \%$ at 7 -d fermentation compared to control and kept stable up to a-28 d fermentation.

\section{Spectra Features}

Typical diffuse reflectance spectra of animal feed samples were shown in Figure 1. Spectra data were consisted of vibrational bonds of $\mathrm{C}-\mathrm{H}, \mathrm{N}-\mathrm{H}, \mathrm{C}-\mathrm{O}-\mathrm{H}$, $\mathrm{C}-\mathrm{C}, \mathrm{O}-\mathrm{H}$ structures in NIR region. These chemical structures represent quality parameters such as protein, fiber, carbohydrates, fat, moisture, and acid content of biological objects. Thus, it is possible for NIRS to predict such quality parameters in near infrared region from wavelength range of 1000 to $2500 \mathrm{~nm}$.

\section{Spectra and Nutritive Value Analyses}

Firstly, spectra data of feed samples were analyzed using principal component analysis to inspect any dissimilarities. Hotelling $\mathrm{T}^{2}$ ellipse was projected onto PCA map to detect outlier data. Data outside the ellipse were noted and removed due to the potential of outliers to affect the accuracy and robustness of the prediction model (Cozzolino et al., 2011; Mouazen et al., 2010). As can be seen in Figure 2, there was no outlier data found since all spectra data were inside the ellipse. Thus, all the total of 25 spectral data were used to predict animal feed nutritive attributes in the form of IVOMD, IVDMD, NDF, and ADF parameters.

\section{IVDMD and IVOMD Prediction}

Prediction results for IVMD and IVOMD parameters are presented in Table 2 and Table 3. Prediction models were quantified and justified using full cross validation method. The accuracy and robustness of prediction model slightly increased when the spectra correction was applied. The best correction methods were achieved using SNV model for both IVDMD and IVOMD. Scatter plots obtained from the best and accurate models were presented in Figure 3.

Table 1. IVDMD, IVOMD, NDF and ADF of sago residues fermented at different period

\begin{tabular}{lccccc}
\hline \multirow{2}{*}{ Variables } & \multicolumn{5}{c}{ Fermentation time (days) } \\
\cline { 2 - 6 } & F0 & F1 & F2 & F3 & F4 \\
\hline IVDMD (\%) & $49.83 \pm 0.34^{\mathrm{d}}$ & $52.59 \pm 0.44^{\mathrm{c}}$ & $53.98 \pm 0.49^{\mathrm{b}}$ & $59.47 \pm 0.31^{\mathrm{a}}$ & $54.84 \pm 0.47^{\mathrm{b}}$ \\
IVOMD (\%) & $51.87 \pm 0.43^{\mathrm{d}}$ & $54.42 \pm 0.45^{\mathrm{c}}$ & $56.30 \pm 0.63^{\mathrm{b}}$ & $63.38 \pm 0.31^{\mathrm{a}}$ & $56.51 \pm 0.39^{\mathrm{b}}$ \\
NDF (\%) & $37.76 \pm 4.19^{\mathrm{a}}$ & $25.39 \pm 0.66^{\mathrm{b}}$ & $26.43 \pm 0.67^{\mathrm{b}}$ & $24.35 \pm 0.54^{\mathrm{b}}$ & $24.86 \pm 1.14^{\mathrm{b}}$ \\
ADF (\%) & $18.10 \pm 0.29^{\mathrm{a}}$ & $16.41 \pm 0.33^{\mathrm{b}}$ & $17.55 \pm 0.43^{\mathrm{a}}$ & $18.09 \pm 0.39^{\mathrm{a}}$ & $17.26 \pm 0.30^{\mathrm{ab}}$ \\
\hline
\end{tabular}

Note: Means within a row with different superscripts differ significantly (P<0.05). F0: Control, F1: 7-d fermentation, F2: 14-d fermentation, F3: 21-d fermentation, F4: 28-d fermentation.
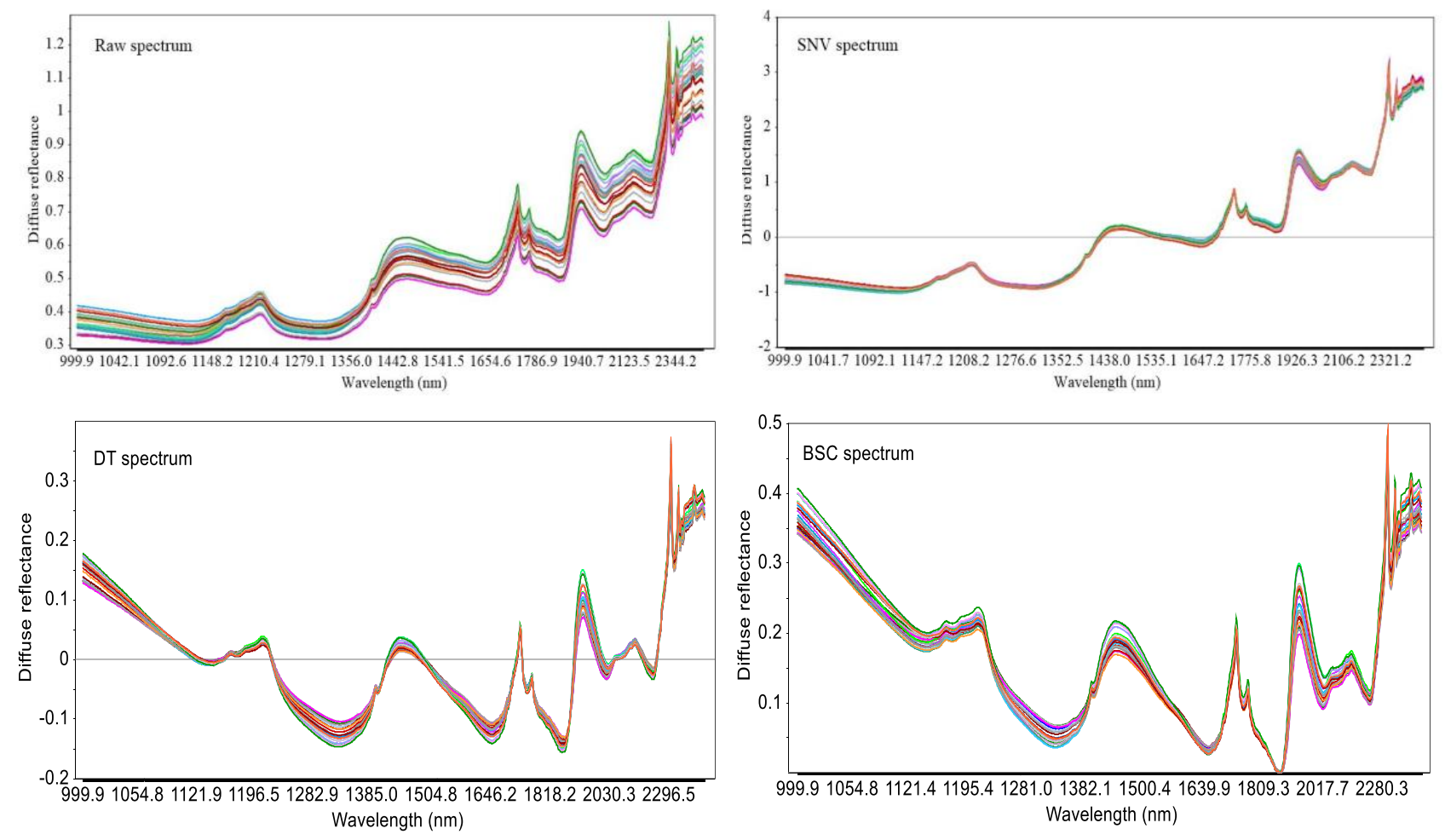

Figure 1. Typical NIR spectra of animal feed samples in wavelength range of $1000-2500 \mathrm{~nm}$. 


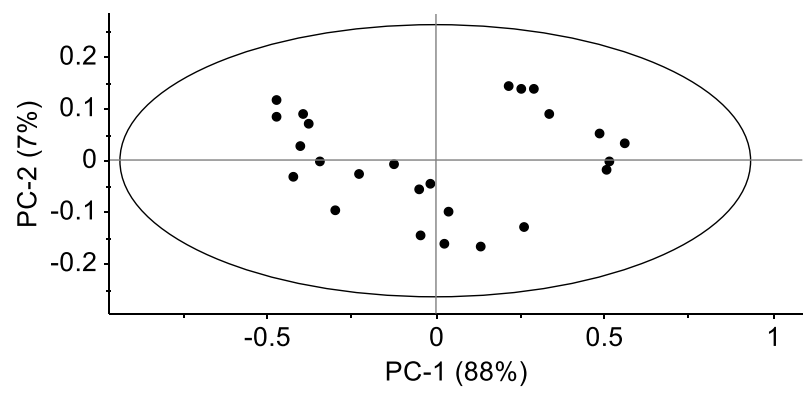

Figure 2. Feed spectra data projected onto PCA and Hotelling T2 ellipse for outliers detection

\section{NDF and ADF Prediction}

In this study, we also attempted to predict and determine other feed quality parameters in the form of detergent fiber (NDF and ADF) nutritive values. Prediction models were also predicted using raw uncorrected spectra and corrected spectra using BSC, SNV, and DT methods. Prediction models were constructed using PCR regression approach and validated using full leave one out cross validation (LOOCV) method. Prediction results for NDF and ADF parameters are presented in Table 4 and Table 5.

Just like IVDMD and IVOMD prediction, NDF could be predicted with the highest accuracy and robustness when the model was constructed using SNV spectra correction method. It generated the highest correlation coefficient of 0.89 and the highest RPD index of 2.31. In addition, the ADF nutritive value can also be predicted well. The best and optimum prediction

Table 2. Prediction results for IVDMD nutritive value of feed samples

\begin{tabular}{cccccc}
\hline \multirow{2}{*}{ Spectrum } & \multicolumn{5}{c}{ Statistical parameters } \\
\cline { 2 - 6 } & $\mathrm{R}^{2}$ & $\mathrm{R}$ & $\mathrm{RMSE}$ & $\mathrm{RPD}$ & $\mathrm{LV}$ \\
\hline Raw & 0.61 & 0.78 & 2.03 & 1.64 & 7 \\
SNV & 0.86 & 0.93 & 1.20 & 2.78 & 6 \\
BSC & 0.72 & 0.85 & 1.72 & 1.94 & 7 \\
DT & 0.72 & 0.85 & 1.71 & 1.95 & 6 \\
\hline
\end{tabular}

Note: BSC: baseline shift correction, DT: de-trending, LV: number of latent variables, $\mathrm{R}^{2}$ : coefficient of determination, $\mathrm{r}$ : correlation coefficient, RMSE: root mean square error, SNV: standard normal variate.

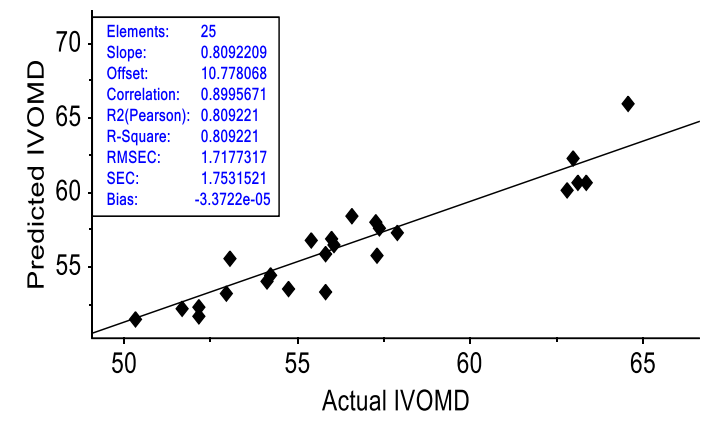

performance was achieved when ADF was predicted using DT spectra correction with a maximum correlation coefficient of 0.94 and RPD index of 3.00 and the number of latent variables required to construct the prediction model was $6 \mathrm{LV}$. Scatter plot driven for NDF and ADF prediction based on SNV and DT are presented in Figure 4.

\section{DISCUSSION}

Sago residue as nonconventional feed have relatively low quality and digestibility. One of the ways to improve the quality and digestibility of agricultural or industrial by-products was by fermentation. The result of the study indicated that fermentation improved IVDMD, IVOMD and reduced the content of NDF and ADF of sago residues (Table 1). The results of this study were in accordance with the research conducted by Samadi et al. (2016) in which sugarcane bagasse fermented with Trichoderma harzianum significantly increased IVDMD and IVOMD. Availability of soluble carbohydrates due to fermentation process was the cause of better IVDMD and IVOMD values. Study conducted by Wajizah et al. (2015) administration of soluble carbohydrates in fermentation increased the percentage of IVDMD. NDF and ADF can be used as indicator for feed quality. The content of NDF and ADF reduced by fermentation. Suryapratma \& Suhartati (2012) also reported that rice straw fermented with white rot fungi and Saccharomyces cerevisiae reduced the content of NDF and ADF.

Near infrared spectrum consists of vibrational bonds of chemical structures such as $\mathrm{C}-\mathrm{H}, \mathrm{C}-\mathrm{H}-\mathrm{O}, \mathrm{N}-\mathrm{H}$,

Table 3. Prediction results for IVOMD nutritive value of feed samples

\begin{tabular}{lccccc}
\hline \multirow{2}{*}{ Spectrum } & \multicolumn{5}{c}{ Statistical parameters } \\
\cline { 2 - 6 } & $\mathrm{R}^{2}$ & $\mathrm{R}$ & $\mathrm{RMSE}$ & $\mathrm{RPD}$ & $\mathrm{LV}$ \\
\hline Raw & 0.59 & 0.77 & 2.51 & 1.60 & 8 \\
SNV & 0.81 & 0.90 & 1.71 & 2.35 & 6 \\
BSC & 0.75 & 0.86 & 1.96 & 2.05 & 7 \\
DT & 0.69 & 0.83 & 2.18 & 1.84 & 6 \\
\hline
\end{tabular}

Note: BSC: baseline shift correction, DT: de-trending, LV: number of latent variables, $\mathrm{R}^{2}$ : coefficient of determination, $\mathrm{r}$ : correlation coefficient, RMSE: root mean square error, SNV: standard normal variate.

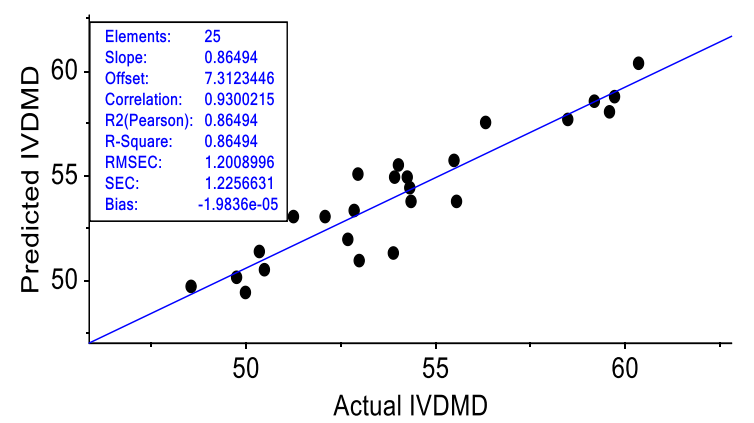

Figure 3. Actual and predicted IVDMD and IVOMD based on PCR-SNV prediction model 
Table 4 Prediction results for NDF nutritive value of feed samples

\begin{tabular}{cccccc}
\hline \multirow{2}{*}{ Spectrum } & \multicolumn{5}{c}{ Statistical parameters } \\
\cline { 2 - 6 } & $\mathrm{R}^{2}$ & $\mathrm{r}$ & RMSE & RPD & $\mathrm{LV}$ \\
\hline Raw & 0.72 & 0.85 & 3.09 & 1.93 & 7 \\
SNV & 0.80 & 0.89 & 2.58 & 2.31 & 6 \\
BSC & 0.78 & 0.88 & 2.71 & 2.20 & 7 \\
DT & 0.79 & 0.89 & 2.65 & 2.25 & 6 \\
\hline
\end{tabular}

Note: BSC: baseline shift correction, DT: de-trending, LV: number of latent variables, $\mathrm{R}^{2}$ : coefficient of determination, $\mathrm{r}$ : correlation coefficient, RMSE: root mean square error, SNV: standard normal variate.

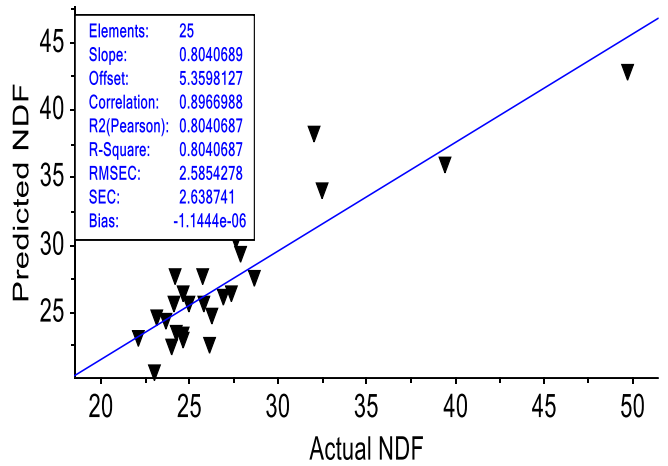

Table 5. Prediction results for ADF nutritive value of feed samples

\begin{tabular}{cccccc}
\hline \multirow{2}{*}{ Spectrum } & \multicolumn{5}{c}{ Statistical parameters } \\
\cline { 2 - 6 } & $\mathrm{R}^{2}$ & $\mathrm{r}$ & $\mathrm{RMSE}$ & $\mathrm{RPD}$ & $\mathrm{LV}$ \\
\hline Raw & 0.77 & 0.87 & 0.45 & 2.13 & 7 \\
SNV & 0.85 & 0.92 & 0.35 & 2.74 & 6 \\
BSC & 0.85 & 0.92 & 0.36 & 2.66 & 6 \\
DT & 0.88 & 0.94 & 0.32 & 3.00 & 6 \\
\hline
\end{tabular}

Note: BSC: baseline shift correction, DT: de-trending, LV: number of latent variables, $\mathrm{R}^{2}$ : coefficient of determination, $\mathrm{r}$ : correlation coefficient, RMSE: root mean square error, SNV: standard normal variate.

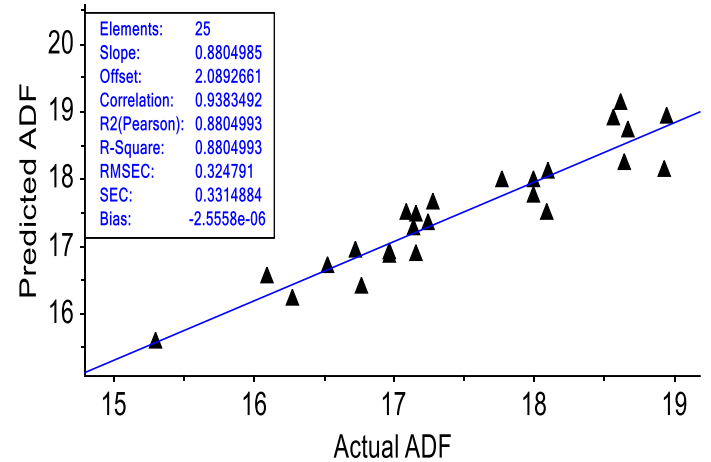

Figure 4. Actual and predicted NDF based on PCR-SNV, and ADF based on PCR-DT prediction model

$\mathrm{O}-\mathrm{H}, \mathrm{R}-\mathrm{O}-\mathrm{H}$, and C-C. These bonds are vibrated as certain wavelength in near infrared region when biological sample is irradiated by incident light. Every biological object has a specific feature and electro-optic property depends on its chemical and physical structures (Munawar et al., 2016). Featured spectra, as are shown in Figure 1, represent chemical properties of feed samples which are related to their nutritive values. Furthermore, spectra data were corrected and enhanced using different spectra pre-processing methods: BSC, SNV, and DT.

In this study, SNV spectra corrected additive and multiplicative effects by scaling the spectra data to its ideal spectrum which was normally the mean spectra of the presented data (Figure 1). On the other hand, DT and BSC correction methods were more focused on enhancing the qualities of their baseline trends. These results are also in agreement with those reported by Cen \& He (2007) and Azzouz et al. (2010) that DT and BSC methods worked well in correcting baseline spectra due to the curvature movements and physical effects during the measurement of spectra data. Further, spectra data were then analyzed to predict the desired quality parameters in the forms of IVDMD, IVOMD, NDF, and ADF nutritive values.

Cen \& He (2007) defined that in NIRS, there were three steps that must be followed: (1) spectra data acquisition (2) spectra correction, and (3) the development of prediction models. After spectral projection and spectra correction, we developed and constructed prediction models that could be used to predict inner quality parameters of feed samples. First of all, we developed prediction models to determine IVDMD and IVOMD parameters using all spectra data (raw spectrum, BSC, SNV, and DT spectrum). Principal component regression was used as a regression approach to correlate between spectra data and actual IVDMD and IVOMD parameters. Prediction models were quantified and justified using full cross validation method.

As can be seen in both tables (Tables 3 and 4) that IVDMD and IVOMD can be predicted sufficiently and coarsely using raw uncorrected spectra data with correlation coefficient of 0.78 for IVDMD and 0.77 for IVOMD, with RPD index of above 1.5 (1.64 for IVDMD and 1.60 for IVOMD). Based on literature, an RPD between $1.5-1.9$ means that coarse quantitative prediction is possible, but still need some improvements in calibration. A value between 2 and 2.5 indicates that the prediction model is sufficient. Meanwhile, an RPD value between 2.5 and 3 or above corresponds to a good and excellent prediction accuracy, respectively (Williams, 2001; Fearn 2002; Nicolai et al., 2007).

The accuracy and robustness of a prediction model were slightly increase when the spectra correction was applied. All spectra correction methods improve accuracy and robustness to a maximum correlation coefficient for IVDMD (0.93) and IVOMD (0.90) (Tables 3 and 4). In addition, the robustness of RPD index was also improved to a maximum of 2.78 for IVDMD and 2.35 for IVOMD which was categorized as a good model performance. In comparison, other findings (Shepherd et al., 2005) showed that NIRS could predict IVDMD in organic residues with correlation coefficient of 0.91 .

Meanwhile, for ADF and NDF predictions, as can be seen in Table 5, the accuracy and robustness of NDF 
prediction performance is sufficient even using raw uncorrected spectra data with correlation coefficient and residual predictive deviation indexes of 0.85 and 1.93, respectively. When the prediction model was developed using corrected spectra of BSC and DT, the accuracy of prediction was slightly improved with RPD index increased to 2.20 using BSC and to 2.25 using DT spectra correction methods. DT spectrum was also improved when we observed the decreased number of latent variables required to establish the prediction model. Just like IVDMD and IVOMD prediction, NDF can be predicted with the highest accuracy and robustness when the model is constructed using SNV spectra correction method. It generated the highest correlation coefficient of 0.89 and the highest RPD index of 2.31. Moreover, the number of latent variables was also decreased to 6 and an error coefficient in the form of RMSE was decreased to 2.58 .

In addition, the ADF nutritive value can also be predicted well even without spectral data correction with correlation coefficient of 0.87 and RPD robustness index of 2.13. The best and optimum prediction performance was achieved when ADF was predicted using DT spectra correction with a maximum correlation coefficient of 0.94 and RPD index was 3.00 and the number of latent variables required to construct the prediction model was $6 \mathrm{LV}$.

In general, obtained prediction results for all quality feed nutrient parameters (IVOMD, IVDMD, NDF, and ADF) are categorized as good and sufficient model performance. To obtain more robust and more accurate prediction result, further spectra correction methods and regression approaches may be employed. These methods including non-linear regression approaches such as support vector egression (SVR) and regression method based on artificial neural network (ANN) may be considered since both methods are more adaptable to spectra data (Munawar et al., 2016).

\section{CONCLUSION}

NIRS technique is feasible to be used and applied in determining quality parameters of feed samples in the form of IVDMD, IVOMD, NDF, and ADF content with good accuracy and robustness performances. The maximum correlation coefficient between the actual and predicted quality attributes were: 0.93 for IVDMD, 0.90 for IVOMD, 0.89 for NDF, and 0.94 for ADF. Moreover, it may also be concluded that employing spectra correction can obviously improve the prediction performances for all quality parameters. SNV and DT found to be the most accurate and optimum spectra correction for feed quality parameter predictions.

\section{ACKNOWLEDGEMENT}

This research was supported by Syiah Kuala University Grand under H-Index scheme in 2016. The authors thank to Ms. Dian Anggraeni at IPB, Laboratory Test and Feed Certification Bekasi, West Java, Ilham and M. Hanafiah at Unsyiah for their helps in data and chemical analysis.

\section{REFERENCES}

AOAC. 2012. Officials Methods of Analysis. 15th ed. Association of Official Analytic Chemists, Arlington, VA.

Azzouz, T., A. Puigdomenech, M. Aragay, \& R. Tauler. 2003. Comparison between different pre-treatment methods in the analysis of forage samples using near-infrared diffuse reflectance spectroscopy and partial least-squares multivariate calibration method. Analytica Chimica Acta 484:121-134. https://doi.org/10.1016/S0003-2670(03)00308-8

Balabin, R. M. \& E. I. Lomakina. 2011. Support vector machine regression as an alternative to neural networks (ANN) for analytical chemistry? Comparison of nonlinear methods on near infrared (NIR) spectroscopy data. Analyst 136:1703-1712. https://doi.org/10.1039/c0an00387e

Balabin, R. M. \& S. V. Smirnov. 2011. Melamine detection by mid and near infrared (MIR/NIR) spectroscopy: a quick and sensitive method for dairy products analysis including liquid milk, infant formula, and milk powder. Talanta 85: 562-568. https://doi.org/10.1016/j.talanta.2011.04.026

Cen, H. \& Y. He. 2007. Theory and application of near infrared reflectance spectroscopy in determination of food quality. Trends in Food Science \& Technology 18: 72-83. https://doi. org/10.1016/j.tifs.2006.09.003

Cozzolino, D., W. U. Cynkar, N. Shah, \& P. Smith. 2011. Multivariate data analysis applied to spectroscopy: Potential application to juice and fruit quality. Food Research International 44:1888-1896. https://doi. org/10.1016/j.foodres.2011.01.041

Fearn, T. 2002. Assessing calibrations: SEP, RPD, RER and R2. NIR News, 13, 12-14. https://doi.org/10.1255/nirn.689

Huang, H., H. Yu, H. Xu, \& Y. Ying. 2008. Near infrared spectroscopy for on/in-line monitoring of quality in foods and beverages: a review. Journal of Food Engineering 87: 303313. https://doi.org/10.1016/j.jfoodeng.2007.12.022

Mouazen, A. M., B. Kuang, J. De Baerdemaeker, \& H. Ramon. 2010. Comparison among principal component, partial least squares and back propagation neural network analyses for accuracy of measurement of selected soil properties with visible and near infrared spectroscopy. Geoderma 158: 23-31. https://doi.org/10.1016/j.geoderma.2010.03.001

Munawar, A.A., D.V. Hoersten, E. Pawelzik, J. K. Wegener, \& D. Moerlein. 2016. Rapid and non-destructive prediction of inner quality attributes of intact mango using Fouriertransform infrared and chemometrics. J. Engineering in Agriculture, Environment and Food 9: 208-215.

Nawi, N. M., G. Chen, T. Jensen, \& S. A. Mehdizadeh. 2013. Prediction and classification of sugar content of sugarcane based on skin scanning using visible and shortwave near infrared. Biosystems Engineering, 115: 154-161. https://doi. org/10.1016/j.biosystemseng.2013.03.005

Nicolai, B. M., K. Beullens, E. Bobelyn, A. Peirs, W. Saeys, K. I. Theron, \& J. Lamertyn. 2007. Nondestructive measurement of fruit and vegetable quality by means of NIR spectroscopy: a review. Postharvest Biology and Technology, 46: 99-118. https://doi.org/10.1016/j.postharvbio.2007.06.024

Porep, J. U., D. R. Kammerer, \& R. Carle. 2015. On-line application of near infrared (NIR) spectroscopy in food. Trends in Food Science \& Technology, 46: 211-230. https://doi. org/10.1016/j.tifs.2015.10.002

Samadi \& P. Yu. 2011. Dry and moist heating-induced changes in protein molecular structure, protein subfraction, and nutrient profiles in soybeans. J. Dairy Sci. 94:6092-6102. https://doi.org/10.3168/jds.2011-4619

Samadi, K. Theodoridou, \& P. Yu. 2013. Detect the sensitivity and response of protein molecular structure of whole canola seed (yellow and brown) to different heat processing methods and relation to protein utilization and availability using ATR-FT/IR molecular spectroscopy with 
chemometrics. Spectrochimica Acta Part A: Molecular and Biomolecular Spectroscopy 105 :304-313. https://doi. org/10.1016/j.saa.2012.11.096

Samadi, S. Wajizah, \& Sabda. 2015. Peningkatan kualitas ampas tebu sebagai pakan ternak melalui fermentasi dengan penambahan level tepung sagu yang berbeda. Agripet. 15:104-111. https://doi.org/10.17969/agripet.v15i2.2849

Samadi, S. Wajizah, Y. Usman, D. Riyatsyah, \& Z. Al Firdausya. 2016. Improving sugarcane bagasse as animal feed by aminiation and followed by fermentationwith Trichoderma harzianum (in vitro study). Animal Production 18: 14-21. https://doi.org/10.20884/1.anprod.2016.18.1.516

Samadi, S.Wajizah \& A. A. Munawar. 2018. Fast and simultaneous prediction of animal feed nutritive values using near infrared reflectance spectroscopy. In C. T. Bull, I. T. Riley, E. Munir, A. R. Alimon, P. Hariyadi, A. Kabutey, D. B. Weaver, R. Llewelyn, C. Sumantri, E. Purba, R. Sigalingging \& Onrizal (Eds). International Conference on Agriculture, Environment, and Food Security 7-8 November 2017, Medan. https://doi.org/10.1088/1755-1315/122/1/012112

Santoso, B., B. Tj Hariadi, V.Sabariah, \& T. Sraun. 2014. Fermentation quality in vitro nutrient digestibility of fresh rice straw-based silage treated with lactic acid bacteria. Med. Pet. 37:115-120. http://dx.doi.org/10.5398/medpet.2014 .37.2.115

Shepherd, K.D., B. Vanlauwe, C. N. Gachengo, \& C. A. Palm. 2005. Decomposition and mineralization of organic residues using near infrared spectroscopy. Plant and Soil 277: 315-333. https://doi.org/10.1007/s11104-005-7929-y

Suryapratama, W \& F. M. Suhartati. 2012. Fermentasi jeramai padi dengan menggunakan white rot fungi dan suplementasi Saccharomyces cerevisiae pengaruhnya terhadap kecernaan nutrient secara in vitro. Agripet 12:1-6. https:// doi.org/10.17969/agripet.v12i2.195

Tilley, J.M.A. \& R. A. Terry. 1963. A two stage technique for the in vitro digestion of forage crops. J. Br. Grass: 18: 104-112. https://doi.org/10.1111/j.1365-2494.1963.tb00335.x

Tsenkova, R., S. Atanassova, K. Itoh, Y. Ozaki, \& K. Toyoda. 2011. Near infrared spectroscopy for biomonitoring: cow milk composition measurement in a spectral region from 1,100 to 2,400 nanometers. J. Anim. Sci. 78: 515-522. https:// doi.org/10.2527/2000.783515x

Wanapat, M., S. Polyrach, K. Boonnop, C. Mapato, \& A. Cherdthong. 2009. Effect of treating rice straw with urea and calcium hydroxide upon intake, digestibility, rumen fermentation and milk yield of dairy cows. Livest. Sci. 125:238-243. https://doi.org/10.1016/j.livsci.2009.05.001

Wajizah, S, Samadi, Y. Usman, \& E. Mariana. 2015. Evaluasi nilai nutrisi dan kecernaan in vitro pelepah kelapa sawit (oil palm fronds) yang difermentasi menggunakan Aspergillus niger dengan penambahan sumber karbohidrat yang berbeda. Agripet. 15: 13-19. https://doi.org/10.17969/agripet. v15i1.2286

Williams, P. C. 2001. Implementation of Near-Infrared Technology. In P. C. Williams, \& K. H. Norris (Eds.), Near Infrared Technology in the Agricultural and Food Industries. American Association of Cereal Chemist., St. Paul, Minnesota, USA. Pp. 145-169.

Wiryawan, K.G., A. Saefuddin, A.M. Fuah, R. Priyanto, L. Khotijah, \& S. Suharti. 2017. Fermentation characteristis and nitrogen retention of Madura cattle fed complete rations containing soybean pod and by-products. Med. Pet. 40:28-34. https://doi.org/10.5398/medpet.2017.40.1.28 